\title{
On the Relationship Between Knowing and Doing in Procedural Learning
}

\author{
Jon R. Star \\ Combined Program in Education and Psychology; University of Michigan; Ann Arbor, MI 48109-1259 \\ Tel: 734-936-2752, Fax: 734-615-2164 \\ Email: jonstar@umich.edu
}

\begin{abstract}
The relationship between learners' knowledge of concepts and their ability to execute procedural skills is an important issue that has been explored in several different fields in cognitive science. A review of some of the existing literature within the domain of mathematics learning indicates that little useful theory has been developed to explain how conceptual knowledge and procedural knowledge are related. A primary reason for this deficiency is that knowledge of concepts is treated as a multi-faceted and rich construct, while procedural knowledge is very narrowly defined and operationalized. Philosophical and historical foundations for this differential treatment are discussed. It is suggested that distinguishing between knowledge type and depth of knowledge illuminates alternative ways in which procedural knowledge can be known and understood. A re-conceptualization of procedural knowledge is presented and implications for future research are discussed.
\end{abstract}

Keywords: mathematics education, learning theory, cognitive science

\section{Introduction}

What is the relationship between learners' knowledge of concepts and their ability to execute procedural skills? This important question has been explored in several different fields within cognitive science. In mathematics education, the relationship between concepts and procedures has been examined in order to better understand children's tendencies to learn algorithms by rote without developing any understanding of what they are doing (Hiebert, 1986). In developmental psychology, articulating how procedures and concepts interact is critical to an understanding of how development occurs (Rittle-Johnson \& Siegler, 1998). In cognitive psychology, both the learning of concepts (Medin, 1989) and the acquisition of procedural skill (Anderson, 1982) are well-studied, but the relationship between them after successful acquisition is not. In philosophy, the question of the relationship between knowing and doing has a very rich past (Ryle, 1949).

In this theoretical paper, I draw from research in each of these approaches. I examine how knowledge of procedures and concepts has been studied and what conclusions have been reached about the relationship between them. From the collected evidence, it appears that little useful theory has been developed to explain how conceptual knowledge and procedural knowledge are related. I then postulate reasons for this deficiency and suggest alternative ways in which this topic can be conceptualized and studied.

\section{Conceptual and Procedural Knowledge}

In the domain of mathematics, several studies of conceptual and procedural knowledge have been conducted, primarily in the domains of counting, single-digit addition, multi-digit addition, and fractions. Table 1 shows a sampling of studies on the relationship between conceptual and procedural knowledge from these four domains.

Three observations from the existing literature on the relationship between concepts and procedures in children's mathematics learning can be made from the examples in Table 1. First, most research in this area has tried to determine the optimum developmental relationship between concept and procedure learning - e.g., "Which comes first?" It is generally agreed that knowledge of concepts and knowledge of procedures are positively correlated and that the two are learned in tandem rather than independently (Hiebert \& Lefevre, 1986; Rittle-Johnson \& Siegler, 1998). However, there continues to be disagreement on the order in which children come to have these types of knowledge and how knowledge of one affects the acquisition of the other. In a review of the literature on this issue, Rittle-Johnson and Siegler (1998) conclude that there is no fixed order in the acquisition of mathematical skills versus concepts. In some cases, skills are acquired first; in other situations, the order is reversed (Rittle-Johnson \& Siegler, 
Table 1. Operationalization of procedures and concepts across several domains and studies (adapted from RittleJohnson \& Siegler, 1998)

\begin{tabular}{|c|c|c|c|c|c|}
\hline Domain & $\begin{array}{l}\text { Sampling of } \\
\text { studies }\end{array}$ & Concept example & Assessment & $\begin{array}{c}\text { Procedure } \\
\text { example }\end{array}$ & Assessment \\
\hline Counting & $\begin{array}{c}\text { Fuson, 1988; } \\
\text { Gelman \& } \\
\text { Gallistel, } \\
\text { 1978/1986; } \\
\text { Gelman \& Meck, } \\
\text { 1983; } \\
\text { Gelman, Meck, \& } \\
\text { Merkin, 1986 }\end{array}$ & $\begin{array}{l}\text { one-to-one, stable } \\
\text { order, cardinality, } \\
\text { abstraction, order } \\
\text { irrelevance } \\
\text { principles }\end{array}$ & $\begin{array}{l}\text { Child recognizes incorrect } \\
\text { assertions about principles or } \\
\text { incorrect execution of } \\
\text { procedures. }\end{array}$ & $\begin{array}{l}\text { Ability to } \\
\text { count }\end{array}$ & $\begin{array}{l}\text { Child can } \\
\text { successfully } \\
\text { count. }\end{array}$ \\
\hline $\begin{array}{l}\text { Single- } \\
\text { digit } \\
\text { addition }\end{array}$ & $\begin{array}{c}\text { Baroody \& } \\
\text { Gannon, 1984; } \\
\text { Siegler \& } \\
\text { Crowley, 1994; } \\
\text { Siegler \& Jenkins, } \\
1989\end{array}$ & $\begin{array}{l}\text { commutativity } \\
\text { principle; need to } \\
\text { represent each } \\
\text { addend in an } \\
\text { addition problem } \\
\text { only once }\end{array}$ & $\begin{array}{l}\text { Child verbally evaluates } \\
\text { legitimacy of novel } \\
\text { procedures; accurately } \\
\text { judges and verbally indicates } \\
\text { whether two similar problems } \\
\text { yield the same answer; } \\
\text { invents and chooses to use } \\
\text { the 'min' procedure }\end{array}$ & $\begin{array}{l}\text { Ability to } \\
\text { add single- } \\
\text { digit } \\
\text { numbers }\end{array}$ & $\begin{array}{c}\text { Child can } \\
\text { successfully } \\
\text { add single- } \\
\text { digit } \\
\text { numbers }\end{array}$ \\
\hline $\begin{array}{c}\text { Multi- } \\
\text { digit } \\
\text { addition }\end{array}$ & $\begin{array}{c}\text { Davis \& } \\
\text { McKnight, 1980; } \\
\text { Fuson, 1990; } \\
\text { Hiebert \& } \\
\text { Wearne, 1996; } \\
\text { Resnick \& } \\
\text { Omanson, } 1987\end{array}$ & Place value & $\begin{array}{l}\text { Child identifies correctly and } \\
\text { incorrectly worked out } \\
\text { addition problems; indicates } \\
\text { the place value of digits } \\
\text { within a number; creates a } \\
\text { correct concrete } \\
\text { representation of multidigit } \\
\text { numbers using Dienes } \\
\text { blocks; teaches a puppet to } \\
\text { add multidigit numbers. }\end{array}$ & $\begin{array}{l}\text { Ability to } \\
\text { add } \\
\text { multidigit } \\
\text { numbers }\end{array}$ & $\begin{array}{c}\text { Child can } \\
\text { successfully } \\
\text { add multi- } \\
\text { digit } \\
\text { numbers }\end{array}$ \\
\hline Fractions & $\begin{array}{c}\text { Baroody \& Hume, } \\
\text { 1991; } \\
\text { Byrnes \& Wasik, } \\
\text { 1991; } \\
\text { Lembke \& Reys, } \\
\text { 1994; } \\
\text { Mack, } 1990\end{array}$ & $\begin{array}{l}\text { Two numbers within } \\
\text { fraction represent a } \\
\text { single quantity; } \\
\text { units equal in size } \\
\text { are necessary to add } \\
\text { or subtract fractions; } \\
\text { same amount can be } \\
\text { represented with } \\
\text { different fractions }\end{array}$ & $\begin{array}{l}\text { Child can identify a written } \\
\text { fraction given a shaded } \\
\text { portion of an object; can } \\
\text { compare the relative } \\
\text { magnitude of different } \\
\text { fractions; can choose } \\
\text { different but equivalent } \\
\text { pictorial representations of } \\
\text { fractions }\end{array}$ & $\begin{array}{l}\text { Ability to } \\
\text { add or } \\
\text { multiply } \\
\text { fractions }\end{array}$ & $\begin{array}{c}\text { Child can } \\
\text { successfully } \\
\text { multiply or } \\
\text { add } \\
\text { fractions. }\end{array}$ \\
\hline
\end{tabular}

1998, p. 105). While this conclusion may be accurate, it is not a particularly powerful or parsimonious foundation for developing a theory of how children learn mathematical concepts and procedures.

Second, the topics studied in this area have been limited to elementary school mathematics. Almost all of the studies are from the topic areas of counting, single-digit addition, multi-digit addition, and fractions -- all areas of study in elementary school. Notably absent are studies of the development of procedural and conceptual knowledge in algebra, geometry, and calculus. Third, these examples reveal that knowledge of concepts and knowledge of procedures are assessed in very different ways. Knowledge of concepts is often assessed verbally and through a variety of tasks. It appears that conceptual knowledge is complex and multi-faceted: One needs to ask children many different kinds of questions in order to accurate gauge the depth, richness, and quality of their conceptual knowledge. By contrast, procedural knowledge is assessed non-verbally by observing the execution of a procedure. Procedural knowledge is viewed as an entity that a student either has or does not have. In other words, a student either knows how to do a procedure (and therefore can execute it successfully) or does not know how to do the procedure. 
I conclude that the current literature on procedural and conceptual knowledge in mathematics has not produced particularly useful or coherent theory. Research that asks the question, "Which comes first", has provided the answer, "It depends." Furthermore, research in this area has been limited to the concepts and procedures of a relatively small portion of the school mathematics curriculum -- that of elementary school. Finally, and perhaps most importantly, the operationalization and assessment of procedures and concepts has been carried out in very different ways. It is this final point that I wish to explore in more depth. The current assumption in the field is that the endpoint of acquisition for concepts is when factual or principled knowledge can be used to recognize, identify, explain, evaluate, judge, create, invent, compare, and choose (see Table 1); in other words, when such knowledge is "understood". By contrast, the endpoint of acquisition of procedures is when skills become routine and can be executed with fluency; in other words, when such knowledge has become automatized. The differential treatment of procedural knowledge and conceptual knowledge (see Table 2) is largely responsible for the field's failure to develop useful theory. I claim that this differential treatment is neither well-founded nor justified.

Table 2. Depiction of procedural and conceptual knowledge in existing literature

\begin{tabular}{|c|c|}
\hline Knowledge type & Endpoint of acquisition \\
\hline Procedural Knowledge & Fully compiled; automatized \\
\hline Conceptual Knowledge & Understood \\
\hline
\end{tabular}

\section{Historical Origins}

A brief examination of the historical and philosophical origins of the terms "procedural knowledge" and "conceptual knowledge" is useful in supporting my claim. The modern distinction about knowledge of concepts and knowledge of procedures has its origins in a philosophical framework which relates "knowing how" and "knowing that" (Ryle, 1949, 1958; Scheffler, 1965). In the present discussion, it is important to note that Ryle introduced this distinction not as an end onto itself but instead as a way to argue for the rejection of a particular philosophical perspective -- that of Cartesian dualism (Ryle, 1949). Cartesianism argues for the duality of mind and body -- in other words, that the mind and the body are distinct from one another. The mind is entirely responsible for thought and controls the body while the body "mindlessly" makes the mind's thoughts come to action. According to this point of view, an individual is intelligent if he/she has an intelligent mind; the body's actions cannot be viewed as exhibiting intelligence, other than through the works of the mind.

Ryle disagreed with Cartesianism, and was in favor of uniting the mind and body through the idea of intelligent action. He felt that there exist activities or actions which have "mind-ful" qualities but are neither products of the mind nor are the effects of the products of the mind. In other words, Ryle felt that action could be performed intelligently or stupidly; indeed, the ability of an individual to do certain sorts of actions is how we make the determination of whether the individual is intelligent or not. The particular categories of knowledge that Ryle introduced to make this argument were "knowing that" and "knowing how." Cartesianism holds that "knowing that" is the province of the mind and "knowing how" is the province of the body (and thus must be the result of the mind's thoughts (Ryle, 1949). According to Ryle, Cartesianists would argue that a performance of a skill ("knowing how") can be deemed intelligent if and only if the individual is thinking (in the mind) about what he/she is doing while actually performing the skill:

The chef must recite his recipes to himself before he can cook according to them [Cartesianists]; the hero must lend his inner ear to some appropriate moral imperative before swimming out to save the drowning man; the chess-player must run over in his head all the relevant rules and tactical maxims of the game before he can make correct and skillful moves. To do something thinking what one is doing is, according to this legend, always to do two things; namely to consider certain appropriate propositions, or prescriptions, and to put into practice what these propositions or prescriptions enjoin. It is to do a bit of theorizing and then to do a bit of practice. (Ryle, 1949, p. 29)

Ryle (1949) proposes instead that a performance can be considered intelligent even when it is not comprised of the sequential operations of theorizing followed by practicing; in other words, that "knowing how" cannot be defined in terms of "knowing that" (p. 32). Performing an action intelligently means thinking about what one is doing while it is being done (cf. Skemp, 1987); such an intelligent performance is one, special action rather than an action with special, intelligent forethought only. 
It is Scheffler (1965) who seems to bring Ryle's earlier work closer to the current concepts/procedures distinction. Scheffler defines "knowing that" as knowledge of propositions or facts. In contrast, "knowing how" involves knowledge of procedures (p. 14); in other words, "the possession of a skill, a trained capacity, a competence, or a technique" (p. 92). Scheffler (1965) notes that skills can be of two types: routine competencies (also called facilities) or critical skills (p. 98), which Ryle refers to as intelligent performances (Ryle, 1949, p. 29). Routine competencies are characterized by automatic, rote performance; by contrast, critical skills are those whose performance is characterized by "careful, skillful performance in which the agent would be commonly described as thinking what he is doing while he is doing it" (Scheffler, 1965, p. 98).

\section{Types and Qualities of Knowledge}

It is interesting to note that Ryle and Scheffler viewed "knowing that" as a fairly straightforward (and perhaps even uninteresting) type of knowledge. Facts were seen as being either known or unknown. In contrast, "knowing how" was the more interesting and complex type of knowledge. Ryle and Scheffler felt that there are qualitatively different ways in which one can "know how". "Knowing how" is quite complex and multi-faceted; one can possess routine competencies, at one end of the knowledge quality continuum, or intelligent performances, at the other. In current research, as shown above, this situation is reversed: Knowledge of concepts is considered to be the more interesting and complex type of knowledge. There are qualitatively different ways in which one can know mathematical concepts; for example, concepts can be "understood," at one extreme, or memorized at the other. Knowledge of procedures, on the other hand, is considered to be straightforward. Procedures or skills are either known or not known.

These distinctions, while appearing to refer to a single dimension of knowledge, actually collapse many dimensions into one. For "knowing how", which appears to be a single knowledge type (knowledge of skills), there are actually multiple ways in which one can "know how". Similarly, conceptual knowledge appears to be a single knowledge type (knowledge of principles or facts), but there are actually many ways in which concepts can be known. Many other terminological distinctions that have been introduced to refer to different aspects of knowledge (e.g., generic/domain-specific, formal/informal, elaborated/compiled, implicit/explicit, and tacit/inert) reflect this tendency to collapse many dimensions into one.

In an attempt to describe knowledge more parsimoniously, de Jong (de Jong \& Ferguson-Hessler, 1996) argues for separating two independent characteristics of knowledge often combined into one: the type of knowledge and the quality of knowledge. Type of knowledge is the more familiar of de Jong's independent characteristics of knowledge. Both of the knowledge distinctions discussed in this paper refer to the same two types of knowledge: knowledge of principles versus knowledge of skills. de Jong (de Jong \& Ferguson-Hessler, 1996) identifies several different qualities of knowledge; the one which is most useful in the present discussion is the depth of knowledge. "Depth of knowledge" refers to the extent that knowledge is "firmly anchored in a person's knowledge base and external information has been translated to basic concepts, principles, or procedures from the domain in question" (de Jong \& Ferguson-Hessler, 1996, p. 107). The dimensions of depth of knowledge are surface (superficial) versus deep, with the implication that surface is poor and deep is good (cf. Chi, Bassok, Lewis, Reimann, \& Glaser, 1989; Ericsson \& Charness, 1994). Deep-level knowledge is associated with comprehension and abstraction and with critical judgement and evaluation (de Jong \& Ferguson-Hessler, 1996). Deep-level knowledge has been structured and stored in memory in a way that makes it maximally useful for the performance of tasks, while surface-level knowledge is associated with rote learning, reproduction, and trial and error (Glaser, 1991).

Thus, knowledge can be examined in light of its depth. The current characterization of procedural and conceptual knowledge in Table 2 can be re-examined by disentangling knowledge type and quality (see Table 3 ). Table 3 illustrates how the terms "procedural knowledge" and "conceptual knowledge" have typically been used to refer to only a single dimension of knowledge of skills.

\section{Examining a ???? Cell}

Note the empty cell in Table 3 corresponding to deep knowledge of procedures. The terminological distinction between conceptual and procedural knowledge does not provide a way to consider or even name the knowledge that would belong in this cell. What would knowledge in this cell, which I will refer to as "procedural understanding" (Greeno, 1978), look like? A student having procedural understanding would have deep knowledge of a procedure -- knowledge that is not necessarily linked to the underlying concepts of the procedure or the domain. For 
example, such a student would have deep knowledge of the procedure for adding fractions without knowing about the concept of fraction. Similarly, a student could have deep knowledge of the procedure for adding multi-digit numbers without knowing about the concept of place value. To many who study mathematics education, the prospect that such knowledge -- procedural understanding -- can exist is questionable. A common perception is that, in the absence of conceptual knowledge of place value, a student can only know how to add multi-digit numbers by rote. Similarly, in the absence of conceptual knowledge of fractions, a student can only know the procedure for adding fractions by rote.

Herein lies the problem with researchers' reliance on elementary school mathematics as the predominant domain of inquiry in the study of procedural and conceptual knowledge. It is difficult to conceive of having understanding of a procedure when one only considers the relatively simple and short procedures learned in elementary school. However, what if one considers more complex and abstract procedures, such as those learned in algebra or calculus? Is it possible to conceive of a non-conceptual yet deep way in which a symbolic procedure can be known?

\section{Table 3. Types of qualities of procedural and conceptual knowledge}

\begin{tabular}{|c|c|c|}
\hline Knowledge type & Knowledge quality at endpoint & of acquisition \\
\hline & Superficial & Deep \\
\hline Procedural Knowledge & Fully compiled; Automatized & $? ? ? ?$ \\
\hline Conceptual Knowledge & $? ? ? ?$ & Understood \\
\hline
\end{tabular}

There is some evidence to suggest that such knowledge exists; I mention three descriptions of what "procedural understanding" might look like. First, Davis (1983) writes about the process that a student goes through in planning how to approach an unfamiliar problem. Such planning requires that the student have knowledge of a range of necessary techniques, each with an appropriate cognitive label or "tag" which specifies what the technique can accomplish and its relevant goals and subgoals. This knowledge -- knowing many different procedural techniques, including the goals, operators, and subgoals of each -- can be deeply known and is not conceptual. Second, Ohlsson and Rees (1991) propose that a procedure is executed with understanding when the "problem solver monitors his or her performance on the problem by comparing the successive states of the problem with what he or she knows about the task environment" (p. 108). They propose that there are two types of knowledge of the task environment: One is knowledge of the principles which guide events and objects in the domain (e.g., the "laws of numbers" (p. 109) for arithmetic), and the other is knowledge of the purposes of each step in a procedure. This second type of knowledge about the procedural task environment -- knowing the purposes of each step in a procedure -- is very similar to Davis' (1983) planning knowledge. Third, VanLehn and Brown have written about teleological semantics (VanLehn \& Brown, 1980). The teleological semantics of a procedure is "knowledge about [the] purposes of each of its parts and how they fit together. ... Teleological semantics is the meaning possessed by one who knows not only the surface structure of a procedure but also the details of its design" (p. 95). VanLehn and Brown (1980) note that a procedure can be cognitively represented on multiple levels. On a very superficial level, a procedure may be represented simply as a chronological list of actions or steps; on a more abstract level, a procedure can include planning knowledge in its representation. Planning knowledge includes not only the surface structure (the sequential series of steps) but also "the reasoning that was used to transform the goals and constraints that define the intent of the procedure into its actual surface structure" (p. 107).

According to these three views, to understand a procedure is to have planning knowledge -- knowledge of such things as the order of steps, the goals and subgoals of steps, the environment or type of situation in which the procedure is used, constraints imposed upon the procedure by the environment or situation, and any heuristics or common sense knowledge which are inherent in the environment or situation. This knowledge is abstract (and deep), but not necessarily conceptual; it fits the criteria of one of the ???? boxes in Table 3 .

\section{Implications}

I suggested that the difficulty in the psychological literature of developing a coherent theory of the relationship between knowledge of concepts and knowledge of procedures may be due in part to a failure to consider this other kind of procedural knowledge. The current research emphasis on elementary school procedures tends to obscure the existence of procedural understanding and support the exclusive focus on knowledge of procedures as necessarily superficial or rote. In addition, the current usage of the terms "procedural knowledge" and "conceptual 
knowledge" do not allow an easy way to talk about other ways in which procedures and concepts can be known (see Table 3).

Broadening the current conception of procedural knowledge would have numerous implications for research in mathematics learning and procedural skill acquisition. I mention three. First, this expanded view of procedural knowledge can lead to better theory about the development of conceptual and procedural knowledge. Rather than asking "Which comes first?", it becomes possible to ask more detailed and accurate questions about both surface and deep conceptual and procedural knowledge. Second, re-conceptualizing procedural knowledge can broaden current ways of studying and assessing student understanding. At present, our methods for assessing students' knowledge are impoverished. Understanding is measured by what a student says or does not say. Knowledge of procedures is measured by what a student does or does not do. Considering procedural understanding allows us to explore indirect measures of tapping into students' understanding of mathematics. We can examine the ways in which a student's understanding (both conceptual and procedural) is expressed in procedural performance. Our analyses can focus on how a student can and cannot do and on the character of the knowledge she has (including its depth) which supports her ability to perform. Third, expanding our conception of procedural knowledge allows us to move closer to a vision of critical skills. Ryle $(1949,1958)$ criticized Cartesianists for portraying intelligent action as a bit of theorizing followed by a bit of doing. He argued instead for uniting knowing and doing into one special action. It is this special action, which Skemp described as "knowing what to do and why" (Skemp, 1976, p. 20), that constitutes understanding in mathematics. Re-conceptualizing procedural knowledge reminds us that understanding in mathematics is the synthesis of knowing and doing, not the accomplishment of one in the absence of the other.

In conclusion, this analysis of current research in mathematics learning shows that certain assumptions about procedural and conceptual knowledge have limited our investigations in this area. To move ahead, we need to reconsider what it means to know concepts and to do skills. Only then can we truly begin to understand what it means to understand.

\section{References}

Anderson, J. R. (1982). Acquisition of cognitive skill. Psychological Review, 89(4), 369-406.

Baroody, A. J., \& Gannon, K. E. (1984). The development of the commutativity principle and economical addition strategies. Cognition and Instruction, 1, 321-339.

Baroody, A. J., \& Hume, J. (1991). Meaningful mathematics instruction: The case of fractions. RASE, 12(3), 54-67.

Byrnes, J. P., \& Wasik, B. A. (1991). Role of conceptual knowledge in mathematical procedural learning. Developmental Psychology, 5, 777-786.

Chi, M. T. H., Bassok, M., Lewis, M. W., Reimann, P., \& Glaser, R. (1989). Self-explanations: How students study and use examples in learning to solve problems. Cognitive Science, 13, 145-182.

Davis, R., \& McKnight, C. (1980). The influence of semantic content on algorithmic behavior. Journal of Mathematical Behavior, 3(1), 39-87.

Davis, R. B. (1983). Complex mathematical cognition. In H. P. Ginsburg (Ed.), The development of mathematical thinking (pp. 253-290). New York: Academic Press.

de Jong, T., \& Ferguson-Hessler, M. (1996). Types and qualities of knowledge. Educational Psychologist, 31(2), 105113.

Ericsson, K. A., \& Charness, N. (1994). Expert performance: Its structure and acquisition. American Psychologist, 49(8), 725-747.

Fuson, K. (1988). Children's counting and concepts of number. New York: Springer-Verlag.

Fuson, K. (1990). Conceptual structures for multiunit numbers: Implications for learning and teaching multidigit addition, subtraction, and place value. Cognition and Instruction, 7, 343-403.

Gelman, R., \& Gallistel, C. R. (1978/1986). The child's understanding of number. Cambridge, MA: Harvard University Press.

Gelman, R., \& Meck, E. (1983). Preschoolers' counting: Principles before skill. Cognition, 13(3), 343-359.

Gelman, R., Meck, E., \& Merkin, S. (1986). Young children's numerical competence. Cognitive Development, 1, 1-29.

Glaser, R. (1991). The maturing of the relationship between the science of learning and cognition and educational practice. Learning and Instruction, 1, 129-144.

Greeno, J. G. (1978). Understanding and procedural knowledge in mathematics instruction. Educational Psychologist, $12(3), 262-283$.

Hiebert, J. (1986). Conceptual and procedural knowledge: The case of mathematics. Hillsdale, NJ: Lawrence Erlbaum. 
Hiebert, J., \& Lefevre, P. (1986). Conceptual and procedural knowledge in mathematics: An introductory analysis. In J. Hiebert (Ed.), Conceptual and procedural knowledge: The case of mathematics (pp. 1-27). Hillsdale, NJ: Lawrence Erlbaum Associates.

Hiebert, J., \& Wearne, D. (1996). Instruction, understanding, and skill in multidigit addition and subtraction. Cognition and Instruction, 14(3), 251-283.

Lembke, L. O., \& Reys, B. J. (1994). The development of, and integration between, intuitive and school-taught ideas about percent. Journal for Research in Mathematics Education, 25(3), 237-259.

Mack, N. K. (1990). Learning fractions with understanding: building on informal knowledge. Journal for Research in Mathematics Education, 21, 16-32.

Medin, D. L. (1989). Concepts and conceptual structure. American Psychologist, 44(12), 1469-1481.

Ohlsson, S., \& Rees, E. (1991). The function of conceptual understanding in the learning of arithmetic procedures. Cognition and Instruction, 8(2), 103-179.

Resnick, L. B., \& Omanson, S. F. (1987). Learning to understanding arithmetic. In R. Glaser (Ed.), Advances in instructional psychology (Vol. 3, pp. 41-95). Hillsdale, NJ: Lawrence Erlbaum.

Rittle-Johnson, B., \& Siegler, R. S. (1998). The relation between conceptual and procedural knowledge in learning mathematics: A review. In C. Donlan (Ed.), The development of mathematical skills (pp. 75-110). East Sussex, UK: Psychology Press.

Ryle, G. (1949). The concept of mind. New York: Barnes and Noble.

Ryle, G. (1958). The intellect. In I. Scheffler (Ed.), Philosophy and education . Boston: Allyn and Bacon.

Scheffler, I. (1965). Conditions of knowledge: An introduction to epistemology and education. Chicago: Scott, Foresman, and Company.

Siegler, R. S., \& Crowley, K. (1994). Constraints on learning in nonprivileged domains. Cognitive Psychology, 27, 194-226.

Siegler, R. S., \& Jenkins, E. (1989). How children discover new strategies. Hillsdale, NJ: Lawrence Erlbaum.

Skemp, R. R. (1976). Relational understanding and instrumental understanding. Mathematics Teaching, 77, $20-26$.

Skemp, R. R. (1987). The psychology of learning mathematics. (Expanded American ed.). Hillsdale, NJ: Lawrence Erlbaum.

VanLehn, K., \& Brown, J. S. (1980). Planning nets: A representation for formalizing analogies and semantic models of procedural skills. In R. E. Snow, P. A. Federico, \& W. E. Montague (Eds.), Aptitude, learning, and instruction (Vol. 2, pp. 95-137). Hillsdale, NJ: Lawrence Erlbaum. 